\title{
Liberationist Conversion and Ethnography in the Decolonial Moment: a Finnish Theologian/Ethicist Reflects in South Africa
}

\author{
Elina Hankela
}

As ethnography has become more popular among theologians, scholars have begun a discussion on what it means to do ethnography specifically as a theologian. ${ }^{1}$ Even though empirical theology has been an important aspect of practical theology since the 1990s, some argue that empirical research in theology continues to be methodologically dependent on the social sciences, and urge theologians to think of qualitative research, including theological ethnography, as more than collecting data using social science methods and reflecting on it theologically. ${ }^{2}$ This chapter joins this collective effort to think about ethnography as a method in theology.

The "ethnography and (Christian) ${ }^{3}$ theology" conversation to date is largely centered in North America and Europe, as the references to some of the leading scholars on the topic above and the contributors in some of the recent edited volumes indicate. ${ }^{4}$ This conversation also resonates with anthropologists' growing interest in, and engagement with, the relationship between

1 See Christian Scharen, Fieldwork in Theology: Exploring the Social Context of God's Work in the World (Grand Rapids: Baker Academic, 2015); Pete Ward (ed.), Perspectives on Ecclesiology and Ethnography (Grand Rapids: William B. Eerdmans, 2012); Christian Scharen and Aana Marie Vigen (eds.), Ethnography as Christian Theology and Ethics (London: Continuum, 2011).

2 Eileen Campbell-Reed and Christian Scharen, "Ethnography on Holy Ground: How Qualitative Interviewing is Practical Theological Work," International Journal of Practical Theology 17 , 2 (2013): 232-259. See also Scharen, Fieldwork in Theology; Jennie Barnsley, "Grounded Theology: Adopting and Adapting Qualitative Research Methods for Feminist Theological Enquiry," Feminist Theology 24, 2 (2016): 109-124; Pete Ward, "Ecclesiology and Ethnography with $\mathrm{Hu}$ mility,"StudiaTheologica-NordicJournalofTheology,2016.DOI:10.1080/0039338X.2016.1204363.

3 In this chapter I focus on the Christian theological conversation, and draw in particular on liberation theology; in the future, engaging sources from other religious traditions and religious studies would enrich the conversation.

4 Ward, Perspectives on Ecclesiology; Scharen and Vigen, Ethnography. 
anthropology and theology and the anthropology of Christianity in the Western academia. ${ }^{5}$ Conversely, there is little engagement with the recent wave of writing on ethnography by theologians from Africa. ${ }^{6}$ Therefore, when reading this discourse and participating in the craft in South Africa - as a white Finnish ${ }^{7}$ theologian - the Western inclination of the conversation raises critical questions. Why is it largely Western theologians who are interested in the ethnography conversation? For a Western ethnographer in Africa, besides being questions of research politics more broadly, such questions also relate to the everyday negotiating of one's own positionality: bringing one's white body and Western academic categories into the context of conducting and writing research in/on Africa is not a disinterested enterprise.

In the meanwhile, in the South African academia, which is my immediate context, the quest of decolonizing knowledge and academia as a whole has in the recent years been particularly audible and visible in the context of the fallist movement, a student-led movement directed against the elitism, inaccessibility, and Western foundations and practices of universities. ${ }^{8}$ In 2015 and 2016 student protests called for free education and the decolonization of institutions of higher education and curricula. Simultaneously and together with the students outsourced cleaning and security personnel at universities protested for decent salaries and working conditions. The conversation on decolonialization continues in South African universities to date. In the context of

5 See Philip Fountain and Sin Wen Lau, "Anthropological theologies: Engagements and encounters," The Australian Journal of Anthropology 24 (2013): 227-234; Joel Robbins, "Anthropology and theology: An awkward relationship?" Anthropological Quarterly 79, 2 (2006): $285^{-294 .}$

6 I do not imply that African theologians do not use or discuss qualitative research methods (see e.g. the article by Nadar cited in this chapter). Rather I here refer to the specific conversation on ethnography and theology.

7 The questions I ask stem primarily from my experience as a white person in South Africa, and my reflection likely resonates with white colleagues from different national backgrounds. However, it is also important to note my being Finnish because, one, my being a foreigner in South Africa and, two, my upbringing in a Finnish family, albeit in various countries, impacts on how I ask the questions. Yet I do not enter in any depth in a comparative discussion on the (in)significance of the potential differences between myself and, say, a white South African colleague on the questions at hand. Furthermore, my social class position as a member of the middle-classes naturally impacts on how whiteness manifests in my life, something I share with many, even if not all, white people in the country.

8 See, for instance, Francis Nyamnjoh, \#RhodesMustFall: Nibbling at Resilient Colonialism in South Africa (Bamenda: Langaa RPCIG, 2016); Sarah Godsell, “\#WitsFeesMustFall Op-Ed: On Violent Protest and Solidarity" in Daily Maverick on 19.10.2015, http://www.dailymaverick. co.za/article/2015-10-19-witsfeesmustfall-op-ed-on-violent-protest-and-solidarity/\#.WCrAP3 dh1os, accessed 22.11.2016. 
this decolonial moment, besides thinking of the Western inclination of the current theological conversation on ethnography, a white theologian using anthropological methods is drawn to think of the harmful and racist historical roles played by both theology and anthropology on the continent. ${ }^{9}$

Within this broader context, in this chapter I address the ethics and practice of theological ethnography from a liberationist ${ }^{10}$ perspective. I do this from the particular position of a Finnish theologian/ethicist in South Africa who is motivated by wanting to imagine theological ethnography as part of the decolonizing process in and beyond academia, rather than seeing theology or theological ethnography as either neutral or anti-decolonization. For someone who comes to ethnographic practice from outside anthropology, my choice of this method is first and foremost epistemological. In line with the spirit of the liberationist break with mainstream Western theologies of the 1970s, ${ }^{11}$ ethnography has the potential to equip a researcher to diverge from totalizing or universalizing theories into appreciating how the phenomena at the heart of the liberationist agenda take shape - and change shape - in particular contexts and in relation to particular praxis. ${ }^{12}$ As I have also explicated elsewhere, I am motivated to think about ethnography as a method for liberation theologies

9 Various scholars in different fields have written about the role of Christianity and/or anthropology in the actualization of the project of colonialism and the making of the racist modern/colonial world. See, for instance, Nelson Maldonado-Torres, "AAR Centennial Roundtable: Religion, Conquest, and Race in the Foundations of the Modern/Colonial World," Journal of the American Academy of Religion 82, 3 (2014): 636-665; Musa Dube, "Introduction: The Scramble for Africa as the Biblical Scramble for Africa: Postcolonial Perspectives," in Postcolonial Perspectives In African Biblical Interpretations, eds. Musa Dube, Andrew Mbuvi and Dora Mbuwayesango (Atlanta: SBL, 2012), 1-26; Ramon Grosfoguel, "Decolonizing Post-Colonial Studies and Paradigms of Political-Economy: Transmodernity, Decolonial Thinking, and Global Coloniality," TRANSMODERNITY:Journal of Peripheral Cultural Production of the Luso-Hispanic World 1, 1 (2011); Mogobe Ramose, African Philosophy through Ubuntu (Harare: Mond Books, 2002); Linda Tuhiwai Smith, Decolonizing Methodologies: Research and Indigenous Peoples (London: Zed Books, 1999); Johannes Fabian, Time and the Other: How Anthropology Makes its Object (New York: Columbia University Press, 1983); Chinua Achebe, Things Fall Apart (London: Heinemann, 1958).

10 Here I refer to liberation theologians and scholars in other fields who draw from the method in liberation theologies, such as Paul Farmer, who is quoted in the text.

11 EAтwот, "Final Statement: Ecumenical Dialogue of Third World Theologians, Dar es Salaam, Tanzania, August 5-12, 1976," in The Emergent Gospel: Theology from the Underside of History: Papers from the Ecumenical Dialogue of Third World Theologians, Dar es Salaam, August 5-12, 1976, eds. Sergio Torres and Virginia Fabella (Maryknoll: Orbis, 1978), 259-271.

12 See Allain Cerwonka and Liisa Malkki, Improvising Theory: Process and Temporality in Ethnographic Fieldwork (Chicago: University of Chicago Press, 2007), loc 229. 
because this method at best provides access to understanding and bringing to the center the experiences of those who are in the margins of power, even if it also has the potential to serve a West-centered orientalist project. ${ }^{13}$

The aim of this chapter is to continue this conversation by employing the notion of conversion to engage the practice of ethnography in the context of (South) Africa, particularly when practiced by a white Finnish scholar. The notion of conversion, liberation-theologically understood, provides a locus for thinking of what is required from liberationist ethnography (i.e., ethnography that is informed by liberation theologies, which in turn are defined by the liberationist method ${ }^{14}$ ) if it is to be part of reimagining knowledge and the world in the decolonial moment. While the recent decolonial discourse does not present a model that is radically different from the liberationist model itself, it is engaged with here because it draws particular attention to what conversion would mean in relation to academia, methodology, and theory. Moreover, writing in the context of South Africa, where race remains a key marker of marginalization, race is the main category in the reflection on conversion in this chapter. Besides being deeply interwoven with other forms of marginalization, ${ }^{15}$ be it based on class, gender, orientation, or nationality, race is also a critical topic in itself in the current public debate ${ }^{16}$ and a central category in the fallist discourse that inspires some of the discussion in this chapter.

The particular themes addressed through the lens of conversion arise from my fieldwork experiences. I have conducted ethnographic fieldwork as a theologian/ethicist in the context of different communities in urban South Africa intermittently since 2009. The research context that most profoundly informs my thinking of ethnography in this chapter is that of a church in inner-city Johannesburg where I spent much of year 2009 as a doctoral student, ${ }^{17}$ and my subsequent (research and other) engagement with people I got to know then. I am still in contact with some of the people whom I encountered in 2009 and

13 Elina Hankela, "Ethnographic Research through a Liberationist Lens: Ethical Reflections on Fieldwork," Missionalia 43, 2 (2015): 195-217.

14 For a brief synopsis of my reading of the liberationist method see Hankela 2015.

15 See Natasha Distiller and Melissa Steyn, "Introduction: Under Construction," in Under Construction: "Race" and Identity in South Africa Today, eds. Natasha Distiller and Melissa Steyn (Sandton: Heinemann, 2004), 6.

16 See, for instance, Tinyiko Maluleke, "Racism is So Much More than Words," in Mail \& Guardian on 15.1.2016, http://mg.co.za/article/2016-01-14-racism-is-so-much-more-thanwords, accessed 22.11.2016; Jacques Rousseau, "Hate Speech, Hurtful Speech, Chris Haart and Penny Sparrow," in Mail \& Guardian on 6.1.2016, http://mg.co.za/article/2016-01-o6hate-speech-hurtful-speech-chris-hart-and-penny-sparrow, accessed 22.11.2016.

17 Elina Hankela, Ubuntu, Migration and Ministry: Being Human in a Johannesburg Church (Leiden: Brill, 2014). 
several young Zimbabwean migrants I met at the time participated in my more recent project on migrant belonging. ${ }^{18}$ Our encounters highlight the ways in which race is linked with socio-economic inequality and xenophobia in the South African context.

In the context of Christianity, conversion can be understood to refer to a turn towards God and/or towards the goals and lifestyle that the Christian community attaches to being Christian, or a turn from one faith or religion to another. ${ }^{19}$ As is clear from this definition, the content of conversion depends on context and the theology adhered to. For instance, much of the nineteenth and twentieth-century missionary movement in Africa defined conversion to Christianity as closely connected to conversion to so-called Western "civilization." ${ }^{20}$ Conversely, in liberationist thinking, the "preferential option for the poor"21 (from here on referred to as the preferential option) defines God as taking sides with the oppressed, and ethics can thus be understood as Christians doing the same. Consequently, the preferential option also defines the meaning of conversion. In delineating the notion of conversion, I draw especially on Peruvian theologian Gustavo Gutiérrez' 1984 book, Drinking from Our Own Wells. ${ }^{22}$ According to Gutiérrez, the preferential option demands solidarity with the marginalized,

18 See Hankela, "Ethnographic Research."

19 For definitions of conversion see e.g. W.R.F. Browning, A Dictionary of the Bible, Second edition, (Oxford: Oxford University Press, 2009); John Bowker, The Conscise Oxford Dictionary of World Religions, (Oxford: Oxford University Press, 2000).

20 See, for instance, Jean Comaroff and John Comaroff, Of Revelation and Revolution: Christianity, Colonialism, and Consciousness in South Africa, vol. I (Chicago: University of Chicago Press, 1991), 198-251.

21 The notion of the preferential option for the poor was coined among Catholic liberation theologians in Latin America in the 1970s (Gustavo Gutiérrez, A Theology of Liberation, 15th Anniversary Edition (Maryknoll: Orbis, 1988), xxvi). It is important to note that "the poor" is understood to refer, not only to the materially poor, but to the various categories of marginalization, (see, for instance, Gustavo Gutiérrez and Daniel G. Groody, "Introduction," in The Preferential Option for the Poor beyond Theology, eds. Daniel Groody and Gustavo Gutiérrez (Notre Dame: University of Notre Dame Press, 2014), 2).

22 I recognize the possible problems in choosing a Latin American theologian as the key source when writing in the context of South Africa, even if he is the "father of liberation theology" and even if my choice is informed by Gutiérrez' long-term living and working with poor communities. 
and solidarity requires ongoing conversion. ${ }^{23}$ The choice of the term "option" emphasizes "the freedom and commitment expressed in a decision," ${ }^{24}$ and thus this freedom is also extended to conversion: it is something to which you choose to commit. The process of conversion denotes an epistemological turning towards something, and away from something else, ${ }^{25}$ and in Gutiérrez' text the standpoint of marginalized groups is adopted as the primary place from which to understand God, the neighbor, the church, and society. Risking being simplistic, one can say that, in theological terms, God - but also the norms upon which a more just society can be built - can be encountered in marginalized places and with marginalized people. The turn towards the marginalized, and the consequent concern about structures that hamper human dignity, is a spiritual process. ${ }^{26}$ While for a theologian it is thus the place to seek God (of justice), for an ethicist it is the place to seek the way of justice. The engagement with, and bringing to the center of, the underside of privilege are, in other words, results of a normative position.

Moreover, conversion is a social process that takes place in time and place, a process defined by context. It implies "a certain integration" into the world of the marginalized and "bonds of real friendship." Solidarity takes place "not with 'the poor' in the abstract but with human beings of flesh and bone" with whom one relates as one's equals, and with an understanding of broader structural inequality. ${ }^{27}$ The importance of such everyday engagement is reflected in South African practical theologian Olehile Buffel's critique of the detachment of theologians from communities and his emphasis on the importance of such a community relationship for Black theology of liberation. ${ }^{28}$ American medical

23 Gustavo Gutiérrez, We Drink From Our Own Wells: The Spiritual Journey of a People, 2oth Anniversary Edition (Maryknoll: Orbis, 2003), 106.

24 Gutiérrez, A Theology of Liberation, xxvi.

25 J.N.J. (Klippies) Kritzinger emphasizes the two directions of conversion in this work. He has written about "conversion as consisting of two movements: the turning away from what is wrong and a turning towards a new possibility" in the context of whiteness in South Africa (Cobus Van Wyngaard, "White theology in dialogue with Black Theology: Exploring the contribution of Klippies Kritzinger," HTS Teologiese Studies/Theological Studies 72, 1 (2016), 4). Kritzinger has also written about the conversion of the researcher as an aspect the praxis cycle (J.N.J. Klippies Kritzinger, "Nurturing Missional Integrity." Paper presented at the Annual Meeting of American Society of Missiology, Techny, Illinois, June 18-20, 15).

26 Gutiérrez, We Drink From Our Own Wells, 95, 102-104.

27 Ibid., 104.

28 Olehile Buffel, "Black Theology and the Black Masses: The Need of an Organic Relationship between Black Theology and the Black Masses," Scriptura 105 (2010): 470-480. 
anthropologist and doctor, Paul Farmer, ${ }^{29}$ reflects on Gutiérrez' understanding of conversion and writes that when working in Haiti, rural Haitians became "part of my own conversion, informing my medical practice but also my understanding of both suffering and responses to it." ${ }^{30}$ Relationships and life convert. However, in the context of ethnographic research one must remain clear that it is not the responsibility of the marginalized person or community to convert the privileged for the sake of the latter's becoming a better person; liberationist conversion instead is connected to true solidarity and social transformation.

Lastly, "(i)f conversion is a process, rooted in time and place and in social change, it stands to reason that our claims of causality about it should be modest and subject to revision."31 The direction of conversion cannot be decided in advance. Instead of the marginalized being the target of a converting mission or theological ethnography, they - both the conditions in which they live and their thinking ${ }^{32}$ - are to be at the center of defining the direction of conversion and, since conversion is not an end in itself, the subsequent transformation in the world, including academia. This raises important questions when thinking about ethnography: is it possible to turn away from a setup where the academic observer ultimately has the power to name and claim, or "the epistemological privilege of the observer,"33 towards a place where the interlocutor truly is the chief definer of our collective story?

The liberationist discourse has to some extent been divided between emphases on redistribution and recognition, though these two sides also overlap. When thinking of conversion, the two sides of justice produce different ways of thinking about the limits to conversion: the politics of recognition draws more attention to the social location of the researcher. ${ }^{34}$ It appears that some South African Black theologians have been more cautious about the process of conversion across the race (and related class) boundary than Gutiérrez in his

29 Paul Farmer, "Conversion in the time of Cholera: A Reflection on Structural Violence and Social Change," in In the Company of the Poor: Conversations with Dr. Paul Farmer and Fr. Gustavo Gutiérrez, eds. M. Griffin and J. Weiss Block (Maryknoll: Orbis, 2013), 95-145.

$30 \quad$ Ibid., 102.

$31 \quad$ Ibid., 103.

32 See Gerald West's argument on different liberationist positions on whether interlocutors' knowledge (thinking) of their context and the Bible should or should not be central to liberationist analysis: Gerald West, "Locating 'Contextual Bible Study' within biblical liberation hermeneutics and intercultural biblical hermeneutics," HTS Teologiese Studies/ Theological Studies 70, no1 (2014). http://dx.doi.org/10.4102/hts.v70i1.2641.

33 Pierre Bordieu, The Logic of Practice (Stanford: Stanford University Press, 1990), 14, cited in Scharen, Fieldwork in Theology, loc. 1, 140.

34 Hankela, "Ethnographic Research," 203-204. 
discussion of conversion primarily in a class context. ${ }^{35}$ Yet a liberationist demarcation of the marginalized as the interlocutors requires some crossing over, although that could take many forms. American Black theologian, James Cone, underlines the importance of personal relations if a white person is to grasp race when he observes that Reinhold "Niehbuhr made no effort to engage in dialogue with black religious leaders and scholars or to develop friendship with black people with whom he could learn about race as he did with Jews." ${ }^{36}$ In Cone's view, Niebuhr "lacked the 'heart to feel' [black suffering] as his own" and, therefore, "although he wrote many essays about race ... the problem of race was never one of his central theological and political concerns."37 Such friendships, across different social/symbolic boundaries, should also sensitize one to think of liberationist conversion as a difficult, and at times at a personal level painful, process: questions concerning whether or not, and how, research across race/other boundaries should be done need to be re-asked in changing contexts.

\section{3}

\section{The Decolonial Moment as the Context of Conversion}

Besides relationships, the theories that inform one's ethnography - and one's conversion - naturally make a difference in the research process and its outcomes. Decolonial thought, which emphasizes the need to identify locations and people that lack epistemic power, is one of the discourses that can inform liberationist ethnography today in the same way in which other theories have informed liberationists of other eras. The recent academic decolonial debate, which is anchored in the notions of decoloniality and coloniality/modernity, is largely led by Latin American scholars, including Walter Mignolo, Aníbal Quijano, Ramon Grosfoguel and Nelson Maldonado-Torres, ${ }^{38}$ but there are also scholars participating in this particular discourse in South Africa, such as Sabelo Ndlovu-Gatsheni. While in this chapter I draw particularly from this decolonial school, it is important to note that the quest for, and theorizing of, decolonization itself is not limited to this discourse, and nor do these thinkers stand outside the history of the broader debates - quite the contrary. Rather, intellectuals from different theoretical positions and disciplines, from both

35 Ibid., 201-205.

36 Jamen Cone, The Cross and the Lynching Tree (Maryknoll: Orbis, 2013), 52.

37 Ibid., 41.

38 One also needs to ask whether drawing on the American - whether North or Latin American - scholars' thought applied to ethnography in South Africa is another colonizing moment. 
academic and literary spaces, have engaged with the ideas and realities of colonization and decolonization for decades, with a strong African contribution from across the continent by the likes of Chinua Achebe, Ama Ata Aidoo, Steve Bantu Biko, Allan Boesak, Tsitsi Dangarembga, Ali Mazrui, Achille Mbembe, Kwame Nkrumah, Mercy Amba Oduyoye, Ngugi wa Thiong'o and Mogobe Ramose.

The choice of decolonial thought as a dialogue partner in this chapter, is based on the fact that in the wave of the fallist movement decolonial thought and rhetoric is gaining ground in South Africa in an intensifying way, seemingly contributing to a redefining of the struggle against economic and racial exclusion by the born-free generation. ${ }^{39}$ Moreover, in search of liberationist ethnography at this point in time, I appreciate the focus of the decolonial critique on the universalizing West-centered nature of academic institutions, curricula, and methodologies: decolonial thought challenges the liberationist as a scholar as it focuses attention on academia and the decolonization of knowledge. ${ }^{40}$

According to the decolonial discourse, the modern/colonial world order, the world as we know it today, rests on a geopolitics and body-politics of knowledge ${ }^{41}$ that privilege Western $\mathrm{Man}^{42}$ and turn spaces outside the sphere of

39 See for instance Sabelo Ndlovu-Gatsheni, "The Emergence and Trajectories of Struggles for an 'African University': The Case of Unfinished Business of African Epistemic Decolonisation," Kronos 43 (2017), 51-77. The decolonial emphasis is also impacting on some sections of the theological scholarship: for instance, the 2017 theme of the conference of the Society for Practical Theology in South Africa was on decolonising practical theology. It is also noteworthy that Nelson Maldonado-Torres and Ramon Grosfoguel have active links to South African academia.

40 Since the postcolonial discourse has had a clear impact in South African academia, maybe most visibly through the work of Cameroonian-born philosopher Achille Mbembe, I wish to make it explicit that my choice of decolonial thought as a dialogue partner here is not "instead of" postcolonial thought. Rather, the space and the scope of this chapter do not allow for a comparison of these two schools (see, for instance, Gurminder K. Bhambra, "Postcolonial and Decolonial Reconstructions," Connected Sociologies (London: Bloomsbury Academic, 2014): 117-140). On decolonial thinkers on postcolonialism see, for instance, Marzagora, "The Humanism of Reconstruction"; Joe Drexler-Dreis, "Interview: Nelson Maldonado-Torres," Newsletter CLT 9 (2014): 9-12; Sabelo Ndlovu-Gatsheni, "Why Decoloniality in the 21st Century?," The Thinker: The Journal of Progressive Thought 48 (2013): 15 .

41 Enrique Dussel, Filosofía de Liberación, (Mexico City: Edicol, 1977), (English: Philosophy of Liberation, Orbis, 1985) and Frantz Fanon, Black Skin, White Masks (New York: Grove Press, 1967) respectively in Grosfoguel, "Decolonizing."

42 Grosfoguel, "Decolonizing," 5-6. In the context of South African academia see, for instance, Tinyiko Maluleke and Sarojini Nadar, "Alien Fraudsters in the White Academy: Agency in Gendered Colour," Journal of Theology for Southern Africa 120 (2004): 5-17. 
Western Man into "wastelands"43 in which the imperialism that created them fronts as the remedy. According to the modern/colonial logic, the bodies in these wastelands become "shells" and "shadows"44 that are filled with knowledge from elsewhere. In the academy, the work of a small group of now dead Western men, produced in particular historical settings, continues to comprise the canon in the humanities and social sciences around the world. ${ }^{45}$ Hence Botswanan biblical scholar Musa Dube may lament: "I confess I have taken a full baptism and I am still drowning in the Eurocentric epistemologies, although not without a struggle."46

A key quest of decolonial thinkers is for a reimagining of the geo- and bodypolitics of knowledge, power, and being, of which I will concentrate on knowledge here, while acknowledging that the three are related, and a call for "democratisation of knowledge, de-hegemonisation of knowledge, dewesternisation of knowledge, and de-Europeanisation of knowledge." ${ }^{37}$ While "the Westernized university" is a "Uni-versity" shaped largely around a single geographic experience, decolonial thinkers and movements dream of a "Decolonial Pluri-versity" that serves the whole world. ${ }^{48}$ Such decolonization would mean, according to Martinique-born psychologist Frantz Fanon, "the creation of a new symbolic and material order that takes the full spectrum of human history, its achievements and its failures, into view." 49

Therefore, in the current unequal circumstances that privilege the West, academia is called to take seriously those who think "from and with subalternized racial/ethnic/sexual spaces and bodies"50 instead of thinking about those spaces and bodies. This call includes privileging intellectual and theoretical contributions from the Global South, or from the "underside of

43 Ngugi Wa Thiong'o, Decolonizing of the Mind (Nairobi: Eat African Educational Publishers / Suffolk: James Currey / Portsmouth: Heinemann, 1986), 3.

44 Steve Biko, I Write What I Like (Northlands: Picador Africa, 2004), 30-31.

45 Ramon Grosfoguel, "The Structure of Knowledge in Westernized Universities: Epistemic Racism/Sexism and the Four Genocides/Epistemicides of the Long 16th Century," Human Architecture:Journal of the Sociology of Self-Knowledge, XI, issue 1 (2013): 74. See also Dube, "Introduction"; Nelson Maldonado-Torres, "The Topology of Being and the Geopolitics of Knowledge," City 8, 1 (2004): 29-56.

46 Dube, "Introduction," 18.

47 Ndlovu-Gatsheni, "Why Decoloniality," 15.

48 Grosfoguel, "Structure of Knowledge," 89. See also Ramose, African Philosophy, 3-4.

49 Fanon interpreted by Maldonado-Torres, "Topology of Being," 36.

5o Grosfoguel, "Decolonizing," 4. 
modernity,"51 as a means of imagining a different genealogy of knowledge. ${ }^{52}$ To emphasize this point, Puerto Rican sociologist Ramon Grosfoguel makes a difference between social location, a notion used by many critical scholars, and epistemic location, the latter being the location from which one thinks: an oppressed person may still think like those in dominant positions. ${ }^{53}$ As an ethnographer I also read this as a call for actual tangible engagement with the spaces, bodies, and minds in the "wastelands": not as someone who observes, names, and reports on the "other," but someone who engages with human beings and then writes from the position of seeking justice.

Instead of contributing towards the decolonial ideal of a pluriversity, certain hubs of area studies hardly seem to break the boundaries of the Westernized university: theory often comes from and is (re)produced in the North while the subjects are in the South. ${ }^{54}$ A European ethnographer in Africa should indeed pause to consider the implications of Nigerian intellectual Wole Soyinka's writing on the fictionalizing of Africa: "Africa remains the monumental fiction of European creativity." ${ }^{55}$ However, the question of one's role in the fiction industry is not simply a question for the European by birth. Soyinka proceeds to discuss "neo-fictioning," that is, the role of post-independence African leaders in fictionalizing their own people as part of acquiring power. ${ }^{56}$ The latter, albeit in the context of national politics, underlines the importance of unpacking the implications of coloniality: ${ }^{57}$ simply being from Africa does not mean that one speaks from Africa.

As in the birth of liberation theologies, in decolonial thought epistemology is again/still at the heart of the critique of the West-centered world order. The binaries in these debates might appear simplistic, especially for those of us who have drunk from hybrid wells, but from the perspective of liberationist and decolonial discourses they provide useful points for anchoring the

$5^{1}$ Enrique Dussel, The Underside of Modernity: Apel, Ricoeur, Rorty, Taylor, and the Philosophy of Liberation, Atlantic Highland, NJ: Humanities Press, 1996.

52 See Drexler-Dreis, "Interview."

53 Grosfoguel, "Decolonizing," 6.

54 Ibid., 3 .

55 Wole Soyinka, Of Africa (London: Yale University Press, 2012), 45.

56 Ibid., $47-52$.

57 Coloniality refers to the legacy of colonialism. It refers to the flip side of modernity, to the existing Euro/America-centered power structures that define knowledge production, social relations, and so on that emerge(d) as a product of modern discourses, see, for instance Nelson Maldonado-Torres, "On the Coloniality of Being," Cultural Studies 21, 2-3 (2007), 240-270. 
struggle. ${ }^{58}$ Moreover, in my reading, the decolonial bias towards "other" knowledges and epistemologies clearly resonates with the liberationist preferential option. Yet while the bias of the latter is the founding element in liberationist thinking in an unequal world, Gutierrez emphasizes the need for its conscious pairing with the notion of the universality of God's love. ${ }^{59}$ From a methodological perspective such a pairing creates a fruitful tension between a radical bias and an appreciation of diversity. This aspiration is similar to the positive tension between the decolonial call for a pluriverse/ity and the privileging of subaltern positions.

With this in mind, I now move onto ethnographic practice: How does one go about converting to the standpoint of the marginalized? How does one make that the place to understand and to learn to see the world anew? I approach liberationist conversion in particular through the demand to write "from" and "with," recently re-articulated by the decolonial school of thought. Moreover, someone may ask what, if anything, makes my approach "theological." In reading the following reflection one should thus bear in mind that my aim is not to identify characteristics that are exclusive to theological ethnography, but rather to understand ethnography in the light of the liberationist notion of conversion and, related to it, that of the preferential option. In other words, the following four sections address questions important to doing ethnography as a liberationist - particularly as a white researcher in the context of what can be called the decolonial moment in South Africa.

\section{Converting to Theory from - Not on - Africa}

For me, the researcher, the relationships with the interlocutors and spending time in the spaces they live in means that I change. It is an ethnographic given that the field changes us; ${ }^{60}$ however, it is by no means a given that this change is liberationist in nature. British sociologist and critical scholar of race and migration, Claire Alexander, notes that ethnography has perhaps been "one of the most critically self-reflective" ways of writing, but also that, "there has been

$5^{8}$ See Sara Marzagora, "The Humanism of Reconstruction: African Intellectuals, Decolonial Critical Theory and the Opposition to the "Posts" (Postmodernism, Poststructuralism, Postcolonialism)," Journal of African Cultural Studies 28, 2 (2016): 174.

59 Gutiérrez, A Theology of Liberation, xxvi.

6o James Bielo, "Introduction: Writing Religion." In Missionary Impositions: Conversion, Resistance, and other Challenges to Objectivity in Religious Ethnography, eds. Hillary Crane and Deana Weibel, (Lanham: Lexington Books, 2013), 9. 
no engagement with the contours of race in the research process." 61 Self-reflexivity in itself is not necessarily critical of social structures and systems, such critique being a key aspect of liberation theologies; contemporary urban ethnography, for instance, has been criticized for constituting "depoliticized moral tales." ${ }^{2}$ Without the support of system-critical thought, the ethnographer's conversion towards marginalized places can easily be a turn towards pacifying sympathy or orientalist self-elevation camouflaged in the jargon of cultural relativism, ${ }^{63}$ rather than justice. In other words, choosing to think with marginalized people in the field, but not with those scholars who imagine a different just world and write from marginalized positions within the academia, easily plays into the epistemic imperial agenda of a geographic and body-political data/theory division which Grosfoguel claims characterizes some area studies.

Thus, the first question in regard to the politics of one's ethnographic work arises before one enters the field. Who are the colleagues one thinks with? Kenyan theologian John Mbiti's coinage of an African understanding of personhood then works as a methodological key: "I am because we are; and since we are, therefore, I am"64 is an aphorism that urges a researcher to think of the academic relationships in which one grows and becomes as a scholar and a person. Who informs the theoretical baggage that one carries into the field and weaves into one's writing? ${ }^{65}$ Whose writing does one take seriously enough to engage and challenge? I would not suggest totally discarding the "canon" of the humanities and social sciences. But ethnographers should at the least read the canon, including the Western theological canon, differently, and do this with scholars from other epistemic locations, like postcolonial Biblical scholars have done with the Bible. ${ }^{66}$

If wanting to break away from the imperialist position, which Grosfoguel attributes to certain area studies, when studying African Christianities, the European theologian-ethnographer - like anyone writing on Africa - needs to

$61 \quad$ Claire Alexander, "Introduction: Mapping the issues," Ethnic and Racial Studies 29, 3 (2006): 399 .

62 Loic Wacquant, "Scrutinizing the Street: Poverty, Morality and the Pitfalls of Urban Ethnography," American Journal of Sociology 107, 6 (2002): 1468-1532, quoted in Alexander, "Introduction," 401.

63 See Kwame Appiah, Cosmopolitanism: Ethics in a World of Strangers (London: Penguin Books, 2006), 13-17 on anthropology and relativism.

64 John Mbiti, African Religions and Philosophy, Second edition, (Portsmouth: Heinemann, 1990), 106.

65 See Edward Said, Orientalism (London: Penguin, 2003), 10.

66 See, for instance, Dube, "Introduction." 
turn in particular, though not exclusively, ${ }^{67}$ to African scholars in search of theory. (Thus, one must also question why I draw on Gustavo Gutiérrez from Peru or decolonial thinkers from the Americas in this chapter while writing in South Africa.) The question of what qualifies as theory from Africa complicates this aspect of conversion. The liberationist and decolonial emphases on the impact of experience on one's faith and thinking highlights the necessity of engaging insiders to the geographic, social, and cultural context. Should one then read scholars merely born in Africa, or those who also work in Africa? African scholars who critique Eurocentrism generally, or those who critique it from a particular theoretical perspective? I believe that policing the authenticity of someone's Africanness is not my task as an outsider, nor would it be constructive for the cause. From a liberationist perspective that takes different forms of inequality seriously it is rather important, for a European scholar, to discern manifestations of Western bias in the writing on Africa and to actively and critically engage a variety of system-critical views that in some way speak from Africa. Although not in relation to ethnography, such a turn to theory from Africa can be detected in the work of a white South African theologian Klippies Kritzinger, who since the 1980 os has actively engaged South African Black theologians and the Black Consciousness movement. ${ }^{68}$ Kritzinger's work is also an example of the implications of converting: his personal conversion is further channeled, for instance, into thinking about the requirement of the white church to convert. ${ }^{69}$

Yet a conversion towards theory from the South, or from Africa in particular, cannot be undertaken without careful consideration. In his 2002 book, South African philosopher Mogobe Ramose warns against the eagerness of "the former beneficiaries of apartheid," white people and especially in his context white South Africans, to become authorities in African philosophy at this point

$67 \quad$ Comaroff and Comaroff's (see Jean Comaroff and John Comaroff, Theory from the South: Or, How Euro-America is Evolving towards Africa (London: Routledge, 2016)) appeal to engage theory from the South resonates with the decolonial aim to create a pluriversity with multiple voices. In this book, "we might move beyond the north-south binary, to lay bare the larger dialectical processes that have produced and sustain it." The way of getting there is via "reflection on the contemporary order of things approached from a primarily African vantage, one, as it turns out, that is full of surprises and counterintuitives, one that invites us to see familiar things in different ways" (loc 65).

68 See, for instance, J.N.J. (Klippies) Kritzinger, "Liberating Whiteness: Engaging with the Anti-racist Dialectics of Steve Biko," in The Legacy of Stephen Bantu Biko: Theological Challenges, ed. Cornel W du Toit, 89-113 (Pretoria: Research Institute for Theology and Religion, University of South Africa, 2008); J.N.J. (Klippies) Kritzinger, Black Theology: A Challenge to Mission (Pretoria: UNISA, dissertation, 1988).

69 Van Wyngaard, "White theology in dialogue." 
in time when it serves their interests, "and in that way resurrect the myth that 'man is a rational animal' was not spoken of the African."70 This calls a white researcher to pause: how does one engage African scholars as authorities and critically engage in the conversation from one's social and epistemic location without using white privilege to (attempt to) overtake the conversation? ${ }^{71}$ Indeed, in my doctoral thesis, ${ }^{72}$ I opted for the ubuntu discourse as the theoretical framework. I wanted to find a theoretical frame from the context in which the church I studied was located. Yet, with hindsight, because of the politics of writing on ubuntu in South Africa today referenced by Ramose above, I might now have opted for a different theoretical framework, or at least discussed my positionality in relation to the choice more thoroughly and critically. Overall, the how-question calls for serious engagement, because retreating back into the safe haven of Western thought is not a solution if the decolonization of knowledge is the aim.

The second perspective in regard to academic politics relates to where one thinks about Africa, which is, of course, not separate from whom one thinks with. For myself, being part of local academia in South Africa has been critical for the (unfinished) conversion of my perspectives. ${ }^{73} \mathrm{Had}$ I not spent time in local universities, I suspect that I would not, for instance, have come to understand the multiple ways in which race and white privilege function in these spaces. This insight also converts me to see the same issues in the context of my research, and hopefully makes my research and writing more relevant to the process of liberation in and outside academia.

Along with choosing the theorists one thinks with, another mechanism of consciously positioning oneself in a liberationist space is to aim to write explicitly from one's body. South African Biblical scholar, Sarojini Nadar, encourages this kind of researcher visibility, which has long been central, for instance, to the African feminist scholarship that she represents: "So instead of a white researcher claiming 'not to see colour' in a research project with predominantly black participants, in narrative research the ways in which the researcher and

70 Ramose, African Philosophy, 4.

71 See Maluleke and Nadar, "Alien Fraudsters."

72 Hankela, Ubuntu.

73 See also Hankela, Ubuntu, 8. 
the participants 'see colour' are brought into dialogue." ${ }^{74}$ In theological terms this is another way of taking seriously the particularity point emphasized by liberation theologies. For a white - regardless of nationality - ethnographer working on/in South Africa, the white frame of one's own experience can be an instrument, ${ }^{75}$ in the field and/or in writing, to either hide and solidify white privilege or to highlight and critique the body-politics of modernity/coloniality that are premised on race as the organizing principle. ${ }^{76}$

Writing or listening sympathetically ${ }^{77}$ in itself is thus not sufficient in the context of liberationist ethnography in (South) Africa, especially if the researcher is white or in other ways privileged by the system. In an interview, Mary, an interlocutor who lived in inner-city Johannesburg, was talking about how members of a particular congregation responded to xenophobic attacks in the city by extending support to poor migrants. She made a difference between what she called "sympathy" and "help." The provided support "did help some of the people that are looking for help. Because it also depends whether are you looking for help or are you looking for sympathy." For Mary, those who sought "help" did not want to be "spoon-fed." Similarly, from a liberationist perspective, sympathetic writing about the difficulties in the lives of marginalized people that does not aim to expose structural injustice could be seen as amounting to handouts. On the contrary, exposing the discontinuity between the experiences of oneself and one's interlocutors can be an act of solidarity or "help" - if it reaches towards just transformation through exposing social inequality. ${ }^{78}$

Therefore, even when turning towards engaging with other voices, one does not leave one's body behind. Because of the things that mark my body and the privilege that comes with it, my choosing a decolonial liberationist position would mean that I must attempt to use my body to imagine a different world. If I am to ignore or hide my white frame of reference in the context of engaging black interlocutors, I believe I will easily turn into writing "about them," or about the "native people" as Nadar ${ }^{79}$ comments on some white Western

74 Sarojini Nadar, "Stories are Data with Soul' - Lessons from Black Feminist Epistemology," Agenda 28, 1 (2014): 23.

75 See Bielo, "Introduction," 3.

76 See Sabelo Ndlovu-Gatsheni, "Decoloniality as the Future of Africa," History Compass 13, $10(2015): 488$.

77 Scharen, Fieldwork in Theology, loc 604.

78 See Susan Abraham, Identity, Ethics and Nonviolence in Postcolonial Theory: A Rahnerian Theological Assessment (New York: Palgrave Macmillan, 2007), 113, on Gayatri Spivak, rescue missions and discontinuity.

79 Nadar, "Stories," 23. 
anthropology. When attempting to "put a human face on what is called a body of knowledge" 80 in the context of a white researcher and black interlocutors, both faces must be accounted for. The liberationist aim is then not to understand "black/poor things" or "black/poor problems" in order for them to be solved. Rather, the aim is to understand and challenge social and economic inequality, and this understanding can take shape in the encounter between my social and epistemic location and, for instance, in my recent project, the social and epistemic location of young, black, low-income Zimbabwean migrants. The importance of such encounters is that if I as a white and middleclass academic want to be part of a liberationist movement towards a different decolonial world, I have to reach outside the privileges of my world to learn about systemic inequalities from the other side. Yet I then also have to be careful not to slip from thinking with to turning the gaze to myself and away from the interlocutors.

Furthermore, as already noted, engaging one's own whiteness is not restricted to academic spaces/writing. In the field, thinking from my body has meant conversations, comments and also jokes about race. If I am genuine about thinking from my body with others and making my racial privilege visible, there are no color-blind breaks available; my white presence can hopefully also provide material for black interlocutors to think about (in)justice. For instance, we discussed the interlocutors' experiences of being called amakwerekwere (a derogatory name used for black African immigrants in South Africa) in a focus group with five young Zimbabweans in Soweto. During the session we, for instance discussed the differences, but also similarities, in the usage of the term $k w e r e k w e r e$ and the term umlungu (a white person) that people in certain places call me. In such conversations the difference in our racialized experiences are highlighted: we might all be foreigners, but I am white and middle-class, and that defines my daily experience. As Richie put this: "if someone is saying umlungu ... they are happy, because even the faces like they are expressing the happiness ... But now when they say kwerekwere ... You can see even the tone. Even the face, it's like: I'm insulting." (The group did add that calling white people amabhunu, a word used to refer to Afrikaans-speaking farmers, would in their view be derogatory.) On the other hand, such conversations also provide a space to talk and listen across the race line, in both directions, at the personal level, and result in creative unanticipated conversations. During the session the group also listened to and commented on my negative experiences of having been called umlungu and at the end of it Richie said he had "learnt

$80 \quad$ Obioma Nnaemeka, "Nego-Feminism: Theorizing, Practicing, and Pruning Africa's Way," Journal of Women in Culture and Society, 29, 2 (2003): 363. 
something in this group today ... when we had this discussion just now, when, about umlungu and kwerekwere"; he continued to reflect on how, in the context of discussing xenophobia, "we all said, like I have a name - don't call me by other names. Don't call me Mugabe, don't call me kwerekwere or a group of people," and therefore it should also apply to how they treat members of other groups of people, even when the used name is generally not used in a derogatory sense. After explaining the fundamental differences between the two names, as quoted above, Richie here reflects on the point of convergence in individual experiences of exclusion based on our discussion. Such conversations may have the potential to imagine transformation from another place - if they are not turned to support an individualistic privilege-blind discourse.

The Converting Potential of Life

In my experience, interviews, participant observation, and what I here call "living in relationships" complement one another as tools of dialogue - and of liberationist conversion. Interviews provide a space for the interlocutor to define the world verbally; participant observation provides a systematic method to learn to see what is happening around one, as well as a mirror of the content of interviews; living aware in relationships is akin to what Gutiérrez denotes by "a certain integration." ${ }^{81}$ It refers to the space on the blurry line between research and relationships, research and life as a whole. While interviews and field notes are important and temporally defined aspects of ethnographic work, living in relationships that extend beyond the finalization of a given research project, participating in the social practice of being a community, has been invaluable for my converting.

An example of living in relationships is that as I type the first draft of this chapter in a coffee shop, I am simultaneously communicating with a friend who has also been my interlocutor - about her difficult financial situation. It also refers to the fact that as I work on this chapter, I receive a message that another friend - also an interlocutor in two different research projects - has been taken to hospital and re-organize my work schedule to go and see him. In a liberationist context, living in relationships is about choosing to enter a world in which vulnerability is a norm - without a defined exit moment in mind and will inevitably also touch the researcher, ${ }^{82}$ even if always differently from the ways in which it defines the life conditions of the interlocutors.

$81 \quad$ Gutiérrez, We Drink From Our Own Wells.

82 Thanks to Reggie Nel for our conversation on this issue. 
In this sense, Gutiérrez' emphasis on integrating into the world of the poor pushes one to think of ethnography as relational life rather than as a period in life, something that the origins of the liberationist method in communities of faith and as a pastoral approach also reflect. The emphasis on research taking place in mutual relationships between human beings further resonates with German anthropologist Johannes Fabian's critique of the ways in which anthropology created and represented its object as the "other" that existed in a time different from "ours." ${ }^{83}$ Farmer further critiques such distance creation in a liberationist context: "in times and places where books are usually written and read, it is important that we resist looking away from social suffering and pretending that the world's poorest do live in a country of their own." ${ }^{84}$ Fabian and Farmer's observations on distance support my reading of the relation between relationships and ethnography through a liberationist lens. The idea of living in relationships takes the principle of living in the same world and time as a starting point, and then calls for more reflection on the nature of the ongoing sharing of life - with the motivation of being part of making a just future for all. Farmer's work as a clinician and researcher reflects such sharing as it does not begin or end with research, as does the work of many liberationist theologians in local faith communities.

Living in relationships adds a layer of feeling the world to the layer of listening to stories about the world, and directly informs one's writing. One of the moments of my conversion to understanding a world in which many of my interlocutors lived took place soon after my laptop had been stolen at the church where I was doing fieldwork. ${ }^{85}$ Lots of people witnessed the theft. No one stopped the person who took it. Having been at the church for some time, I could easily think of good reasons for the lack of intervention. Some time passed and I had returned to the church after taking a debriefing break, a distance that I could afford unlike many others in that context. I was sitting on the floor in a corridor when two teenagers came and sat on either side of me. They had heard what had happened, and said they were sorry. Then one of them, Tinashe, empathetically noted: "It's part of life." While at the theoretical level I knew that losing one's material possessions was part of life both at the church and on the streets surrounding it, I (still) did not know this life. Over the years I have returned to this moment. This is not "a part of life" that is easy to

83 Fabian, Time and the Other.

84 Paul Farmer, "Conversion in the time of Cholera: A Reflection on Structural Violence and Social Change," in In the Company of the Poor: Conversations with Dr. Paul Farmer and Fr. Gustavo Gutiérrez, edited by M. Griffin and J. Weiss Block, 95-145 (Maryknoll: Orbis, 2013), 135 .

85 Also reported in Hankela, Ubuntu, $3^{2-33}$. 
comprehend from my epistemic location. Moreover, I am still at times in touch with Tinashe and, through the on-going nature of our encounter, these kinds of moments are also reinterpreted through new layers of the relationship. So, when I code interviews and think of my research questions, these experiences are one influence directing my thinking process. I do not think that such shifting of my perspective to the better understand and feel through another experience - or the rules of another social order - would have been possible without long-term relationships with my interlocutors that transcended research. I do not think that I would have come to think of social justice or to read theorists in ways that I have (and I surely have not arrived yet) if it were not for this sharing of life. There is nothing special about such relationships to the liberationist method in general, other than perhaps the combination of living together and systematically using ethnographic methods that I believe can strengthen liberationist work. Yet it is worth reflecting on, as this is the space to think with.

Importantly though, living in relationships does not have impact on one's epistemic location changing. I still think from my white and middle-class body. However, relationships with people from another epistemic location do impact on my thinking - in a similar way as, for instance, my reading in liberation theologies or decolonial thought. In that sense the epistemic location is not static or absolutely predefined by the social location of the thinking and feeling subject; but nothing will ever provide me access to thinking from the epistemic location of a young, black, low-income Zimbabwean migrant. Neither does the notion of living in relationships allow one to condone an idealisation of poverty by pretending that a professional academic shares the life conditions of the interlocutors: I, for instance, do not; I drive to the suburbs and sleep behind burglar doors.

In discussing the power of life to convert, the focus has been on the conversion of the researcher. Yet the question of what research gives to, or takes from, the interlocutors is no less important from a liberationist perspective. While the community, its thinking and realities, defines conversion, ethnographic practice can also provide the members of the community places of conversion: places to think and rethink their ideological/religious/political positions or to process their life stories. ${ }^{86}$ The idea of the interlocutors' conversion (say towards the dogma of liberationist ethics) also presents critical questions concerning research as a way of colonization. As these questions require more attention than that provided by one section of a chapter, I leave them for the future. 
These relationships have taught me that in order to convert to a liberationist position, one does not have to engage with a conscientized - in the Freirean sense - community of liberationists. Even if not every marginalized person is conscientized to think from the place of being black/poor/female/LGTBI, ${ }^{87}$ the marginalized nevertheless think from a social location defined by their blackness/socioeconomic position/gender/orientation, and that is the place one needs to engage to learn to know differently, and in particular to understand, inequality. My converting has by no means been restricted to conversations and encounters with only the liberationists-at-heart, or self-identified decolonialists, and I find it vital for system-critical scholars not to predetermine the limits to liberationist knowledge or predetermine who may carry, provide, or embody it. Such predetermination would lead to straightjacketing the marginalized person with a higher knowledge of "true" liberation, or, in other words, to claim that knowledge must fit the liberationist frame predefined by oneself. 88

Yet, as a liberationist scholar, I do listen to interlocutors' stories - like every other story in the world - from a particular normative position. ${ }^{89}$ Thus one begins by acknowledging one's own "faith," and its implications for responding to the views of the interlocutor. But as long as it is not a position of "knowing better," but rather one that is open to dialogue and one that acknowledges that conversion to new knowing may take place where the two horizons fuse, in the Gadamerian sense, this does not need to undermine the interlocutor's knowing. Ghanaian theologian Mercy Amba Oduyoye's explanation of how other people's thoughts from other contexts are approached in African women's theology illustrates such dialogue:

Other people's thoughts and arguments become stimulants, and not points of argument aimed at establishing what is definitive. Rather, the approach is that of dialogue as women aim at affirmations, continued questioning of tradition in view of contemporary challenges... ${ }^{90}$

87 Gustavo Gutiérrez, "The Option for the Poor Arises from Faith in Christ," in In the Company of the Poor: Conversations with Dr. Paul Farmer and Fr. Gustavo Gutiérrez, eds. M. Griffin and J. Weiss Block (Orbis, Maryknoll, 2013), 147-159; Grosfoguel, "Decolonizing”; Biko, I Write; Paulo Freire, Pedagogy of the Oppressed (New York: Continuum, 2000).

88 Hankela, "Ethnographic Research," 206; see also Freire, Pedagogy, 90.

89 See Hankela, "Ethnographic Research," 206-207.

9o Mercy Amba Oduyoye, Introducing African Women's Theology (Sheffield: Sheffield Academic Press, 2001), 11. 
I then bring my liberationist thinking into the dialogue, not as a superior knowing but as the place where I begin to question. Sometimes the dialogue begins during the conversation with the interlocutor; at other times it emerges in one's study, between an interview transcription and literature.

For instance, I had already known Richie for a long time when I interviewed him formally. In the interview, talking of the jobs that he did to fund his studies, he said he did not want to describe the "illegal" aspects of one of them. Having a hunch from our previous informal conversations about the nature of what he called illegal, I suspect that I would have instead primarily seen such aspects of this given job as a product of the oppressive and biased, or in other ways "illegal," nature of the framework within which the society functions. Richie's choosing to mention but not elaborate on the "illegal" matters in a recorded interview is telling about what is entailed in conversion to listening to, feeling, and conversing with a person who has a different lived experience. It is not a process of simply being told the incontrovertible "truth" by a given marginalized group of people (e.g., I can disagree with Richie about whether what he thinks is illegal, really should be singled out as illegal in a broader framework), but rather one of learning how, for instance, Richie understands and negotiates his marginalized epistemic and social location through both adapting to an unequal social order and constructing parallel social orders within which to live. And then I, the researcher, think about his understandings and negotiations in relation to the other truths of, for instance, liberationist scholars. ${ }^{91}$

\section{8}

\section{Concluding Thoughts}

If being and becoming human is a relational process, the researcher is part and parcel of either the actualization or the exploitation of the humanity of others. Indeed, because of the potential of research to do either, hard questions of research ethics and practice become fundamental. This is even more pronounced in the context of race and - closely related to race - class. Is sufficient conversion even possible in the context of a white, middle-class, Finnish researcher writing on the experience of low-income black communities and persons in South Africa when one takes into consideration the prevalent geopolitics and body-politics of knowledge? Is liberationist conversion - and the liberationist personal politics of the researcher - enough to stop theological ethnography on Africa from succumbing to the age-old racist tendency of fictionalizing the

91 See Hankela, "Ethnographic Research," 206-207; see also Comaroff and Comaroff, Theory from the South, loc 53, on "grounded theory." 
continent and her people? While the particular questions I ask rise from my positionality, liberationist scholars from other social/epistemic locations, even those that are closer to that of their interlocutors, need to consider similar questions to remain true to the preferential option and on-going conversion.

From the perspective of the preferential option, holistic transformation (economic, political, social, spiritual), or decolonization, is a key measure of liberationist ethnography. For Gutiérrez the preferential option for the marginalized requires solidarity, and solidarity requires conversion. For a privileged academic this cannot happen without crossing over symbolic and/or social boundaries - whether this happens in the field, in terms of theoretical choices, or in friendships. Gutiérrez speaks of "a certain integration" into the world of the marginalized as a critical aspect of a conversion process, and indeed such "integration" as an aspect of research has been one of my converters, even if I prefer to speak of "living in relationships." Long-term relationships, which are not (solely) defined by research, can, one hopes, allow space for real solidarity to emerge, as also implied by Cone above. Yet although the on-going conversion of the privileged researcher might be necessary for her or his being part of a liberationist movement, the researcher's conversion is not the aim of liberationist ethnography: such a conclusion would make a mockery of the preferential option. But if the liberationist movement towards just transformation is the aim, in/through faculties of theology, liberationist ethnography could be a method that promotes that movement.

With this in mind, one must constantly check one's motivation for, and ways of doing, research across social/symbolic boundaries in order not to slip into using the marginalized person as a means of boosting one's career or feeling good about one's politics or solidifying the racist world order: What drives my commitment to this context? Do I manage to reverse unjust power relations through my research in any way? Do my research and writing aim for "the creation of a new symbolic and material order that takes the full spectrum of human history, its achievements and its failures, into view"? ${ }^{92}$ One would then consider both the impact of one's work on academic/societal/ecclesial transformation and, on the other hand, the impact of the research process on the lives of the interlocutors. The nature of relational living emphasizes the fact that the researcher is a responsible human being in relation to the interlocutors - not only in relation to posing a challenge to structures - and vice versa. ${ }^{93}$

If the direction of conversion, and thus the direction of transformation, ought to be defined by the living conditions and thinking of a particular group of marginalized people, one needs to think about the particular context of one's

$92 \quad$ Maldonado-Torres, "The Topology of Being," 36.

93 See also Hankela, "Ethnographic Research," 206. 
research carefully: Is the crossing of social/symbolic boundaries suggested by Gutiérrez' understanding of conversion fruitful in South Africa today? What would it look like in Johannesburg? Can a research project - of a Finnish researcher in the context of a Zimbabwean community - be designed in a way that it becomes a space of reimagining power relations and existing ideas of knowledge instead of solidifying them? Again, these questions remain open for me as the role of self-reflexivity here is not to make oneself feel good but to push the boundaries.

Since the self-understanding generated by liberationist ethnography stems from being part of reimagining the world, one cannot convert in relation to the field and then retreat back into being content in a hipsterdom of liberal scholars. Conversion that is limited to the field does not break away from a geopolitics of knowledge according to which theory comes from the North. In practice, the researcher is responsible for taking the conversion into teaching and academic conversations. Indeed, the decolonial call to decenter Europe in academia also speaks to the liberationist discourse itself, and, for instance, challenges the heavy use of European thought in the writing of some liberationist thinkers.

\section{Acknowledgments}

I would like to thank the editors of this book, Karen Lauterbach and Mika Vähäkangas, as well as Elias Bongmba, Lotta Gammelin, Sarah Marusek and Auli Vähäkangas for their comments on previous drafts of this chapter. I also wish to thank Emil Aaltonen Foundation for funding I received through the Youth at the Margins project (University of Helsinki, Finland).

\section{References}

Abraham, Susan. Identity, Ethics and Nonviolence in Postcolonial Theory: A Rahnerian Theological Assessment. New York: Palgrave Macmillan, 2007.

Achebe, Chinua. Things Fall Apart. London: Heinemann, 1958.

Alexander, Claire. "Introduction: Mapping the issues." Ethnic and Racial Studies 29, no. 3 (2006): 397-410.

Appiah, Kwame. Cosmopolitanism: Ethics in a World of Strangers. London: Penguin Books, 2006.

Barnsley, Jennie. "Grounded Theology: Adopting and Adapting Qualitative Research Methods for Feminist Theological Enquiry," Feminist Theology 24, no. 2 (2016): 109-124. 
Bhambra, Gurminder K. "Postcolonial and Decolonial Reconstructions." Connected Sociologies, 117-140. London: Bloomsbury Academic, 2014.

Bielo, James. "Introduction: Writing Religion." In Missionary Impositions: Conversion, Resistance, and other Challenges to Objectivity in Religious Ethnography, edited by Hillary Crane and Deana Weibel, 1-10. Lanham: Lexington Books, 2013.

Biko, Steve. I Write What I Like. Northlands: Picador Africa, 2004 (1978).

Bordieu, Pierre. The Logic of Practice. Stanford: Stanford University Press, 1990.

Buffel, Olehile. "Black Theology and the Black Masses: The Need of an Organic Relationship between Black Theology and the Black Masses." Scriptura 105 (2010): $470-480$.

Campbell-Reed, Eileen and Christian Scharen. "Ethnography on Holy Ground: How Qualitative Interviewing is Practical Theological Work." International Journal of Practical Theology 17, no. 2 (2013): 232-259.

Cerwonka, Allaine and Liisa Malkki. Improvising Theory: Process and Temporality in Ethnographic Fieldwork. Chicago: University of Chicago Press, 2007.

Comaroff, Jean and John Comaroff. Theory from the South: Or, How Euro-America is Evolving towards Africa. London: Routledge, 2016.

Comaroff, Jean and John Comaroff. Of Revelation and Revolution: Christianity, Colonialism, and Consciousness in South Africa, vol. I. Chicago: University of Chicago Press, 1991.

Cone, James. The Cross and the Lynching Tree. Maryknoll: Orbis, 2013.

Distiller, Natasha, and Melissa Steyn. "Introduction: Under Construction." In Under Construction: "Race" and Identity in South Africa Today, edited by Natasha Distiller and Melissa Steyn, 1-11. Sandton: Heinemann, 2004.

Drexler-Dreis, Joe. "Interview: Nelson Maldonado-Torres," Newsletter CLT 9 (2014): $9^{-12 .}$

Dube, Musa. "Introduction: The Scramble for Africa as the Biblical Scramble for Africa: Postcolonial Perspectives." In Postcolonial Perspectives In African Biblical Interpretations, edited by Musa Dube, Andrew Mbuvi and Dora Mbuwayesango, 1-26. Atlanta: SBL, 2012.

Dussel, Enrique. The Underside of Modernity: Apel, Ricoeur, Rorty, Taylor, and the Philosophy of Liberation, Atlantic Highland, NJ: Humanities Press, 1996.

Dussel, Enrique. Filosofía de Liberación, Mexico City: Edicol, 1977. (English: Philosophy of Liberation, Orbis, 1985).

EATWOT. "Final Statement: Ecumenical Dialogue of Third World Theologians, Dar es Salaam, Tanzania, August 5-12, 1976." In The Emergent Gospel: Theology from the Underside of History: Papers from the Ecumenical Dialogue of Third World Theologians, Dar es Salaam, August 5-12, 1976, edited by Sergio Torres and Virginia Fabella, 259271. Maryknoll: Orbis, 1978. 
Fabian, Johannes. Time and the Other: How Anthropology Makes its Object. New York: Columbia University Press, 1983.

Fanon, Frantz. Black Skin, White Masks. New York: Grove Press, 1967.

Farmer, Paul. "Conversion in the time of Cholera: A Reflection on Structural Violence and Social Change." In In the Company of the Poor: Conversations with Dr. Paul Farmer and Fr. Gustavo Gutiérrez, edited by M. Griffin and J. Weiss Block, 95-145. Maryknoll: Orbis, 2013.

Fountain, Philip and Sin Wen Lau. "Anthropological theologies: Engagements and encounters." The Australian Journal of Anthropology 24 (2013): 227-234.

Freire, Paulo. Pedagogy of the Oppressed, 3oth Anniversary Edition. New York: Continuum, 2000.

Godsell, Sarah. “\#WitsFeesMustFall Op-Ed: On Violent Protest and Solidarity” in Daily Maverick on 19.10.2015, http://www.dailymaverick.co.za/article/2015-10-19witsfeesmustfall-op-ed-on-violent-protest-and-solidarity/\#.WCrAP 3 dhios, accessed 22.11.2016.

Grosfoguel, Ramon. "The Structure of Knowledge in Westernized Universities: Epistemic Racism/Sexism and the Four Genocides/Epistemicides of the Long 16th Century." Human Architecture: Journal of the Sociology of Self-Knowledge, XI, issue 1 (2013): 73-90.

Grosfoguel, Ramon. "Decolonizing Post-Colonial Studies and Paradigms of PoliticalEconomy: Transmodernity, Decolonial Thinking, and Global Coloniality." TRANSMODERNITY:Journal of Peripheral Cultural Production of the Luso-Hispanic World 1, no. 1 (2011).

Gutiérrez, Gustavo. "The Option for the Poor Arises from Faith in Christ." In In the Company of the Poor: Conversations with Dr. Paul Farmer and Fr. Gustavo Gutiérrez, edited by M. Griffin and J. Weiss Block, 147-159. Orbis, Maryknoll, 2013.

Gutiérrez, Gustavo. We Drink From Our Own Wells: The Spiritual Journey of a People, 2oth Anniversary Edition. Maryknoll: Orbis, 2003.

Gutiérrez, Gustavo. A Theology of Liberation, 15th Anniversary Edition. Maryknoll: Orbis, 1988.

Gutiérrez, Gustavo and Daniel G. Groody. "Introduction." In The Preferential Option for the Poor beyond Theology, edited by Daniel Groody and Gustavo Gutiérrez, 1-8. Notre Dame: University of Notre Dame Press, 2014.

Hankela, Elina. "Ethnographic Research through a Liberationist Lens: Ethical Reflections on Fieldwork." Missionalia 43, no. 2 (2015): 195-217.

Hankela, Elina. Ubuntu, Migration and Ministry: Being Human in a Johannesburg Church. Leiden: Brill, 2014.

Kritzinger, J.N.J. (Klippies). "Nurturing Missional Integrity." Paper presented at the Annual Meeting of American Society of Missiology, Techny, Illinois, June 18-20. 
Kritzinger, J.N.J. (Klippies). "Liberating Whiteness: Engaging with the Anti-racist Dialectics of Steve Biko." In The Legacy of Stephen Bantu Biko: Theological Challenges, edited by Cornel W du Toit, 89-113. Pretoria: Research Institute for Theology and Religion, University of South Africa, 2008.

Kritzinger, J.N.J. (Klippies). Black Theology: A Challenge to Mission, Pretoria: UNISA, doctoral dissertation, 1988.

Maldonado-Torres, Nelson. "AAR Centennial Roundtable: Religion, Conquest, and Race in the Foundations of the Modern/Colonial World." Journal of the American Academy of Religion 82, no. 3 (2014): 636-665.

Maldonado-Torres, Nelson. "On the Coloniality of Being." Cultural Studies 21, no. 2 (2007), 240-270.

Maldonado-Torres, Nelson. "The Topology of Being and the Geopolitics of Knowledge." City 8, no. 1 (2004): 29-56.

Maluleke, Tinyiko and Sarojini Nadar. "Alien Fraudsters in the White Academy: Agency in Gendered Colour." Journal of Theology for Southern Africa 120 (2004): 5-17.

Maluleke, Tinyiko. "Racism is So Much More than Words." In Mail \& Guardian on 15.1.2016, http://mg.co.za/article/2016-01-14-racism-is-so-much-more-than-words, accessed 22.11.2016.

Marzagora, Sara. “The Humanism of Reconstruction: African Intellectuals, Decolonial Critical Theory and the Opposition to the 'Posts' (Postmodernism, Poststructuralism, Postcolonialism)." Journal of African Cultural Studies 28, no. 2 (2016): 161-178.

Mbiti, John. African Religions and Philosophy. Second edition. Portsmouth: Heinemann, 1990.

Nadar, Sarojini. “'Stories are Data with Soul' - Lessons from Black Feminist Epistemology." Agenda 28, no. 1 (2014): 18-28.

Ndlovu-Gatsheni, Sabelo. "The Emergence and Trajectories of Struggles for an 'African University': The Case of Unfinished Business of African Epistemic Decolonisation." Kronos 43 (2017): 51-77.

Ndlovu-Gatsheni, Sabelo. "Decoloniality as the Future of Africa." History Compass 13, no. 10 (2015): 485-496.

Ndlovu-Gatsheni, Sabelo. "Why Decoloniality in the 21st Century?" The Thinker 48 (2013): 10-15.

Nnaemeka, Obioma. "Nego-Feminism: Theorizing, Practicing, and Pruning Africa's Way." Signs:Journal of Women in Culture and Society, 29, no. 2 (2003): 357-385.

Nyamnjoh, Francis. \#RhodesMustFall: Nibbling at Resilient Colonialism in South Africa. Bamenda: Langaa RPCIG, 2016.

Oduyoye, Mercy Amba. Introducing African Women's Theology. Sheffield: Sheffield Academic Press, 2001.

Ramose, Mogobe. African Philosophy through Ubuntu. Harare: Mond Books, 2002. 
Robbins, Joel. "Anthropology and theology: An awkward relationship?" Anthropological Quarterly 79, no. 2 (2006): 285-294.

Rousseau, Jacques. "Hate Speech, Hurtful Speech, Chris Haart and Penny Sparrow." In Mail \& Guardian on 6.1.2016, http://mg.co.za/article/2016-o1-o6-hate-speech -hurtful-speech-chris-hart-and-penny-sparrow, accessed 22.11.2016.

Said, Edward. Orientalism. London: Penguin, 2003 (1978).

Scharen, Christian. Fieldwork in Theology: Exploring the Social Context of God's Work in the World. Grand Rapids: Baker Academic, 2015.

Scharen, Christian and Aana Marie Vigen (eds.) Ethnography as Christian Theology and Ethics. London: Continuum, 2011.

Smith, Linda Tuhiwai. Decolonizing Methodologies: Research and Indigenous Peoples. London: Zed Books, 1999.

Soyinka, Wole. Of Africa. London: Yale University Press, 2012.

Van Wyngaard, Cobus. "White theology in dialogue with Black Theology: Exploring the contribution of Klippies Kritzinger," HTS Teologiese Studies/ Theological Studies 72, no. 1 (2016). http://dx.doi.org/10.4102/hts.v72i1.3033.

Wacquant, Loic. "Scrutinizing the Street: Poverty, Morality and the Pitfalls of Urban Ethnography." American Journal of Sociology 107, no. 6 (2002): 1468-1532.

Ward, Pete. "Ecclesiology and Ethnography with Humility." Studia Theologica - Nordic Journal of Theology, 2016. DOI:10.1080/0039338X.2016.1204363.

Ward, Pete (ed.) Perspectives on Ecclesiology and Ethnography, Grand Rapids: William B. Eerdmans, 2012.

Wa Thiong'o, Ngugi. Decolonizing of the Mind: The Politics of Language in African Literature. Nairobi: East African Educational Publishers / Oxford: James Currey / Portsmouth: Heinemann, 1986.

West, Gerald. "Locating 'Contextual Bible Study' within biblical liberation hermeneutics and intercultural biblical hermeneutics." HTS Teologiese Studies/Theological Studies 70, no 1 (2014). http://dx.doi.org/10.4102/hts.v70i1.2641. 